\title{
当科における上腕骨大結節骨折の治療指針
}

\author{
福岡大学医学部整形外科

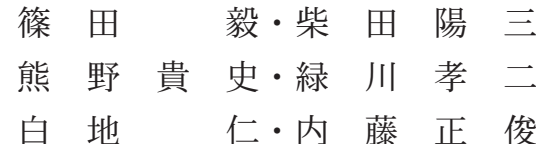

\section{Treatment for Greater Tuberosity Fractures of the Humerus}

Tsuyoshi Shinoda, Yozo Shibata, Takafumi Kumano, Koji Midorikawa, Hitoshi Shirachi, and Masatoshi Naito

Department of Orthopaedic Surgery, Fukuoka University Hospital, Fukuoka, Japan

Clinical results of greater tuberosity fractures of the humerus were studied. Displacement of the greater tuberosity reguiring no reduction was determined. Twenty-two patients (14 men, eight women) were acute injuries (average age 52.5). Seven out of 22 patients underwent conservative treatment. Internal fixation was performed on the remaining 15 cases. Seven chronic patient (six men, one woman) with malunion of greater tuberosity underwent conservative treatment at other clinics. Both acute and chronic cases indicating a more than $4 \mathrm{~mm}$-displaced fragment of greater tuberosity fracture complained of disability due to impingement. We concluded that internal fixation should be performed on these more than $4 \mathrm{~mm}$-displaced fragment of the greater tuberosity fracture.

Key words : greater tuberosity fractures of the humerus（上腕骨大結節骨折）, impingement syndrome（インピンジメント症候群）, internal fixation（内固定）

\section{は じめに}

1970 年 Neer ${ }^{4)}$ の上腕骨近位端骨折に対する 4 part classification では, $1 \mathrm{~cm}$ 未満, あるいは 45 度未満 の回旋転位の上腕骨近位端骨折の治療は整復, 内固定 は不要と述べた。しかし，10mm 未満の転位である minimal displacement と診断された大結節骨折例で, 疼痛や外転障害を訴える症例を散見する。今回我々は 当科における大結節骨折の新鮮例, 陳旧例の治療成績 を調查し，大結節骨折の転位許容度を検討したので報 告する.

\section{対象並びに方法}

大結節骨折を伴う陳旧例と新鮮例の上腕骨近位端骨 折症例である。陳旧例は男性 6 例，女性 1 例，平均年 齢 46.4 才である（表 1 ）。陳旧例は全例，他院にて保
存的加療をうけ大結節変形治癒骨折の診断で当科紹介 となった症例であった。新鮮例は男性 14 例, 女性 8 例, 平均年齢 52.5 才であった。治療方法は陳旧例 7 例中 3 例に大結節骨切り術に前肩峰形成術を併用し, 4 例に前肩峰形成術のみを施行した。新鮮例 22 例中, 7 例に保存療法を, 15 例に観血的整復内固定術を施行 していた．新鮮例，陳旧例共に，単純 X 線所見，日 本整形外科学会肩関節疾患治療成績判定基準（以下 JOA score) で検討した.

$$
\text { 結果 }
$$

新鮮例保存療法群は 7 例で男性 4 例, 女性 3 例, 平 均年齢は 43.7 才であった。全例 Neer の分類で Group 1 であった. 大結節骨片の転位は 0-4 mm で, 治療後の JOA score は 98.6 点であった。 1 例に骨癒 合が得られた後, 肩挙上時痛が継続し, 治療期間の遅 
表 1 陳旧例 7 例の内訳

*大結節骨切り術には前肩峰形成術を含む

\begin{tabular}{|c|c|c|c|c|c|c|}
\hline & 年齢 & 性別 & $\begin{array}{c}\text { 大結節の転位 } \\
(\mathrm{mm})\end{array}$ & $\begin{array}{l}\text { 再建術前 } \\
\text { JOA score }\end{array}$ & 手術 法 & $\begin{array}{c}\text { 術後 JOA } \\
\text { score }\end{array}$ \\
\hline ·症例 1 & 19 & M & 4 & 80.5 & 前肩峰形成術 & 91 \\
\hline · 症例 2 & 65 & $\mathrm{~F}$ & 4 & 47 & 前肩峰形成術 & 71.5 \\
\hline - 症例 3 & 60 & M & 7 & 36.5 & 前肩峰形成術 & 100 \\
\hline · 症例 4 & 49 & M & 5 & 41 & 前肩峰形成術 & 94 \\
\hline ·症例 5 & 40 & M & 7 & 69.5 & 大結節骨切り術 & 89 \\
\hline • 症例 6 & 55 & M & 5 & 69.5 & 大結節骨切り術 & 100 \\
\hline - 症例 7 & 37 & M & 11 & 82.5 & 大結節骨切り術 & 100 \\
\hline - 平均 & 46.4 & & $6.1 \mathrm{~mm}$ & 60.9 & & 92.2 \\
\hline
\end{tabular}

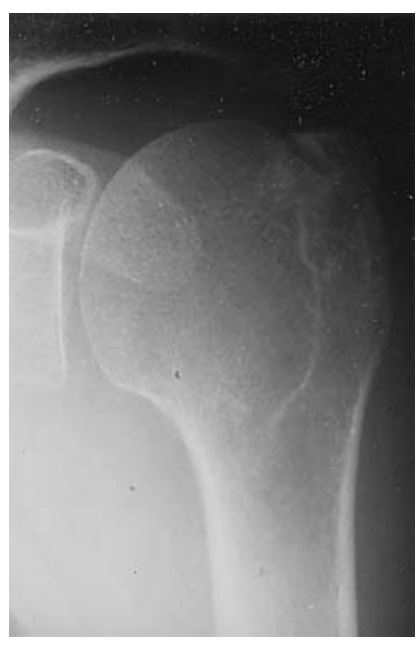

a

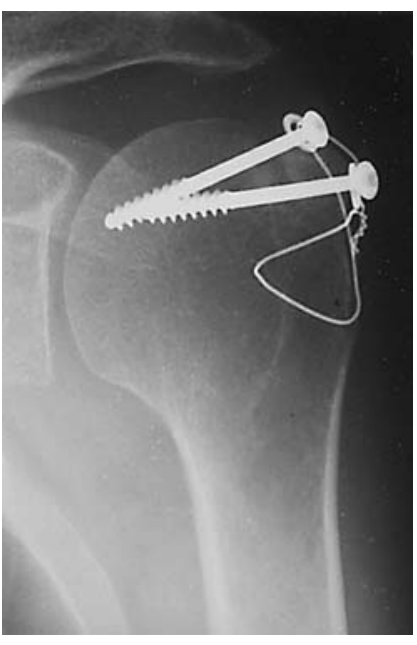

$\mathrm{b}$

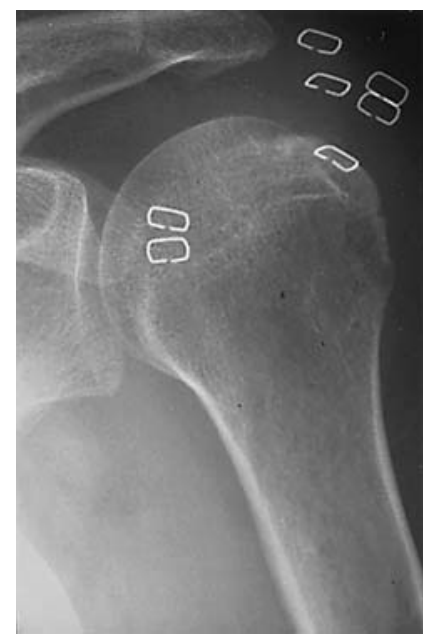

C

図 $1(\mathrm{a}, \mathrm{b}, \mathrm{c})$ 症例 1 の単純 $\mathrm{X}$ 線所見

$\mathrm{a}$ ：大結節が上方へ転位しており変形治癒を呈している

b : 大結節骨切り術後

c ：抜釘術後上方へ転位した大結節は anatomical に整復されている

延がみられた。陳旧例 7 例は男性 6 例, 女性 1 例, 平 均年齢 46.4 才で大結節骨片の転位は $4 \mathrm{~mm}$ から 11 $\mathrm{mm}$, 平均 $6.1 \mathrm{~mm}$ であった. 術前の平均 JOA score は 60.9 点, 術後の平均 JOA score は 92.2 点と改善 を認めた。 新鮮例手術療法群は男性 11 例, 女性 4 例, 平均年齢は 56.5 才であった. Neer の分類で group 1 は 2 例, group 4 は 8 例, group 6 は 5 例であった. 大結節骨片の転位は $4 \mathrm{~mm}$ から $30 \mathrm{~mm}$ で, 治療後の 平均 JOA score は 84.9 点であった.

\section{症 例 供 覧}

症例 1：40才，男性. 1998 年 7 月バイク事故にて 受傷. 左上腕骨大結節脱臼骨折の診断で，他院にて保 存的加療うけるも, 挙上時痛, 可動域制限残存し, 大 結節変形治癒骨折の診断で 1999 年 4 月当科紹介, 入 院となつた.

当科受診時の理学的所見は挙上 130 度, 外転 110 度, 外旋 50 度, 内旋 L3 であった. Impingement test 陽 


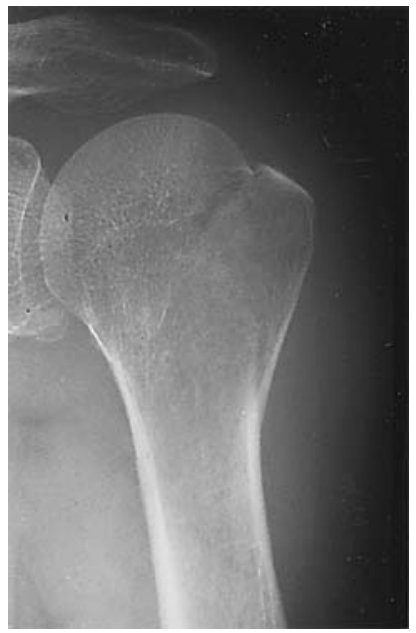

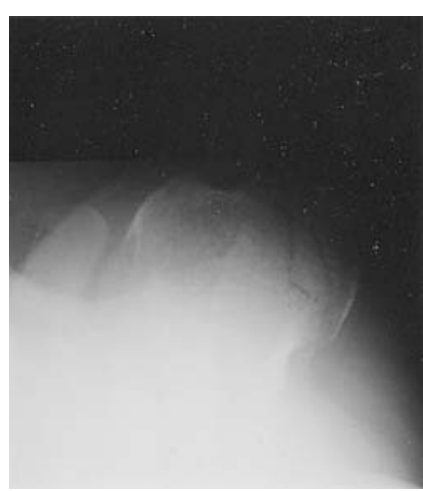

b

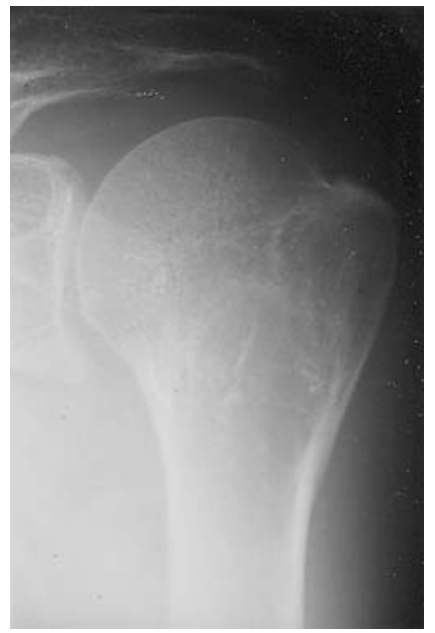

C

図 $2(\mathrm{a}, \mathrm{b}, \mathrm{c})$ 症例 2 の単純 X 線所見

$\mathrm{a}$ ：初診時正面像：大結節は軽度上方へ転位している

b : 初診時結節間溝撮影像 : 大結節の転位は明瞭である

c：受傷後 7 力月：骨癒合は得られるも, 外転時痛が残存している

性. JOA score は 55.5 点. 当科受診時の単純 X 線所 見（図 1-a，b，c）では前後像で $7 \mathrm{~mm}$ 大結節骨片の 上方転位がみられ大結節変形治癒骨折を呈していた. 約 8 力月の保存療法に抵抗し, 挙上時の肩痛残存した ため大結節骨切り術，前肩峰形成術を施行した。術後 8 カ月目に抜釷し, JOA score は 55.5 点から 89 点に 改善した。

症例 2：49才, 男性. 1999 年 8 月自宅内で転倒し, 左手をつき受傷. 直後より左肩痛出現したため当日当 科受診となつた。当科初診時の単純 X 線所見（図 2-a, b， c）で， $4 \mathrm{~mm}$ 大結節骨片の上方転位がみられる. 結節間溝撮影では大結節部の骨折線が明瞭である。治 療は 3 週間体幹固定がおこなわれ，3 週経過後より可 動域訓練， 6 週から腱板強化訓練おこなわれた。受傷 後 7 力月経過時, 骨癒合は得られているが, 挙上時の 痛みが残存していた. JOA score は 90 点であった.

\section{考察}

大結節骨片の転位許容度について諸家の報告があり， Mclaughlin ${ }^{2)}$ は転位が $5 \mathrm{~mm}$ 以内であれば保存療法 にて良好な成績がえられ，5-10mm 以内であれば治 療に長期間を有し障害が残存した症例がみられたと報 告した。 Neer は $10 \mathrm{~mm}$ 未満の転位を，仲川 ${ }^{3)}$ は大結
節の前方部であれば $5 \mathrm{~mm}$ ，大結節後方部のみの骨片 は $10 \mathrm{~mm}$ 以内を保存療法の適応と述べた。保存療法 に抵抗を示す大結節変形治癒骨折後の impingement 症候群に対する治療法として，保坂 ${ }^{1)}$ らは大結節矯正 骨切り術を報告している。当科でも大結節変形治癒骨 折後の impingement syndrome に対し，まず腱板強 化訓練などの保存療法を試み，改善を認めない症例に は前肩峰形成術，大結節矯正骨切り術を施行し良好な 成績を挙げている. 今回, 変形治癒骨折で手術を施行 した 7 例の大結節の転位は $4 \mathrm{~mm}$ から $11 \mathrm{~mm}$ であっ た. 7 例中 4 例は前肩峰形成術のみを行い, 3 例に前 肩峰形成術に大結節矯正骨切り術を併用した。術式の 選択として，当科では術中，前肩峰形成後に肩関節を 外転させ大結節と肩峰の impingement の有無を確認 し, impingement を認める症例には大結節矯正骨切 り術を併用している，新鮮例保存療法群では大結節の 転位は 0 から $4 \mathrm{~mm}$ で，保存療法にてほぼ満足いく 治療結果が得られているが，4 mm 転位を認めた 1 例 は骨癒合後にも肩外転時に疼痛が残存していた。新鮮 例手術療法群 15 例の内, 上腕骨大結節単独骨折例は 4 例あり，術前の大結節の転位は $8 \mathrm{~mm}$ から $23 \mathrm{~mm}$ であった。術後平均 JOA score は 92 点と良好な成 績を挙げている。 今回の研究で，大結節の転位が 4 
$\mathrm{mm}$ と軽微なものであっても impingement を起こす 症例がみられた。それは転位が軽度であっても腱板の たわみが起こり，骨頭の depressor としての機能不全 を生じ impingement をおこすものと考えられた．当 科では年齢, 職業, 活動性など患者の背景を考慮し治 療方針を決定しており，活動性の高い青・壮年で大結 節が $4 \mathrm{~mm}$ 以上転位している症例には積極的に手術 を施行している.

結語

上腕骨大結節骨折については $4 \mathrm{~mm}$ 以上の転位が あれば手術を積極的に考慮すべきである。

\section{参 考 文 献}

1）保坂正人ほか：上腕骨近位端変形治癒後の impingement syndrome に対する大結節矯正骨切り術の経験. 中部整災誌, $30: 1636-1641,1987$.

2) McLaughlin, H. L.: Dislocation of the shoulder with tuberosity fracture. Surg Clin North America, $43: 1615-1620,1963$.

3）仲川喜之ほか：上腕骨大結節骨折. MB Orthop, 10 (7)： 51-59, 1997.

4) Neer, C. S. II : Displaced proximal humeral fracture Part I. Classification and evaluation. J bone joint Surg, 52-A : 1077-1089, 1970. 